\title{
Joëlle ZASK, La Démocratie aux Champs
}

Paris, La Découverte, 2016, 256 pages

\section{Céline Henne}

\section{(2) OpenEdition \\ 1 Journals}

\section{Electronic version}

URL: http://journals.openedition.org/ejpap/1413

DOI: $10.4000 /$ ejpap. 1413

ISSN: 2036-4091

\section{Publisher}

Associazione Pragma

\section{Electronic reference}

Céline Henne, "Joëlle ZASk, La Démocratie aux Champs », European Journal of Pragmatism and American Philosophy [Online], X-2 | 2018, Online since 11 January 2019, connection on 10 December 2020. URL http://journals.openedition.org/ejpap/1413; DOI : https://doi.org/10.4000/ejpap.1413

This text was automatically generated on 10 December 2020 .

\section{(c) $\Theta \Theta \Theta$}

Author retains copyright and grants the European Journal of Pragmatism and American Philosophy right of first publication with the work simultaneously licensed under a Creative Commons AttributionNonCommercial-NoDerivatives 4.0 International License. 


\title{
Joëlle ZASK, La Démocratie aux Champs
}

\author{
Paris, La Découverte, 2016, 256 pages
}

\section{Céline Henne}

\section{REFERENCES}

Joëlle ZASK, La Démocratie aux Champs, Paris, La Découverte, 2016, 256 pages

1 In her book La Démocratie aux Champs, French philosopher Joëlle Zask wishes to overturn the longstanding prejudice according to which democratic ideals essentially grow out of and thrive in big cities, and are antithetical to agricultural life. Whether in 19th century Europe or in contemporary United States, peasants are widely seen as conservative, bigoted and apolitical, while urban residents typically represent a more progressive and politically minded population. Against this view, but also against the alternative view of a romanticized and idyllic rural world, Zask defends the idea that the values and practices associated with democratic freedom "primarily come [...] from the farm" (p. 7). "Farm" is to be understood broadly: the scope of her book is not restricted to the peasant lifeworld, but encompasses different kinds of agriculture, including urban community gardens.

2 Zask is not the first one to defend such a view. Most of the empirical material used to support her philosophical arguments comes from existing historical and sociological studies describing democratic practices, experiences and modes of organization in collective farms, community gardens or peasants' political movements. The originality of Zask's book lies in the scope of her argument and in the use she makes of these local experiments to defend a more general claim about the nature of democracy. Already existing studies are most often published as articles and always focus on particular experiments (e.g., Jefferson's “ward republics," jardins ouvriers in 19th century France, New York City's community gardens). In contrast to these studies, Zask's book is the first extensive study that makes a general claim about the democratic benefits of growing and cultivating land, gathering and articulating these independent studies into a broader philosophical and political perspective. 
3 In her presentation of farming practices and communities as the cradle of democracy, Zask is adopting a conception of democracy that is essentially pragmatist, and more specifically Deweyan. She rejects the view of democracy as a mere system of government, comprising particular electoral procedures and a number of civil rights and liberties. For Zask - as for Dewey - democracy is a "way of life," a set of practices based on social involvement and cooperation that foster opportunities for selfcultivation. In Zask's words, her focus on agricultural practices is meant to convey an image of democracy as a "garden" rather than a "machine" (12), and as a social and political system which is not as much about deliberation and decision-making, as it is about "doing together (faire ensemble)" (15).

The book is easily accessible to readers that are familiar with neither pragmatism nor contemporary political philosophy. Instead of giving a systematic presentation of theoretical ideas, articulated in deductive arguments and illustrated by case studies, Zask proceeds in a very pragmatist fashion, by starting from the study of concrete experiments, thus introducing political and philosophical ideas in a very intuitive manner. This methodology also reflects a voluntary take on what democratic theory should be about: not a utopian ideal or distant horizon, but the generalization of practices that already exist and have proven successful.

While Zask is well-known in France as a specialist of Dewey's political philosophy (see L'opinion publique et son double, in two volumes: Livre I: L'opinion sondée; Livre II : John Dewey, philosophe du public, Paris, L'Harmattan, 1999-2000), Dewey's name is mentioned only a few times in this book, almost always en passant. But pragmatist concepts and ideas are used throughout the book as tools to bring out particular features of the practices that she is describing. This makes her book a very good introduction to the pragmatist conception of democracy, as well as to her own political philosophy, which she exposed in one of her previous books Participer. Essai sur les formes démocratiques de la participation (Le Bord de l'eau, 2011).

The book is divided into four chapters, each focusing on a specific aspect of the relation between agriculture (broadly speaking) and democracy. I will now present the main arguments of each chapter, and conclude with some critical remarks.

7 While the title of the book (Democracy in the fields) portended a topic centered on rural communities, with an expected emphasis on collective organization, Zask surprisingly starts her book with a first chapter on the cultivation of the individual, entitled "cultivation of land, cultivation of self" (culture de la terre, culture de soi). She explains this choice by stating that in democracy, groups and individuals are not antagonistic, quite the contrary: "individuals benefit from the group as much as groups benefit from individual contributions; the more assertive, cultivated and balanced individuals are, the more active and energetic the groups they constitute" (19). Zask makes it clear that, in her view, the "individual" should not be seen as a static and finished product, but as a process: and indeed, the chapter is much more about individuation than individuality per se.

8 The central idea of the chapter is that freedom and individuation are two inseparable democratic values, particularly instantiated in and fostered by the activity of cultivating land. After an introductory part - perhaps longer than it needed be, for philosophical purposes - on foundational myths which equate the birth of agriculture with that of civilization, she turns to the ideal of the independent farmer in Jefferson's America. 
Jefferson was guided by the idea that individuals can only flourish by participating actively in the organization of their own existence (36). By choosing to go back to Jefferson's conception of the democratic ideal as that of "self-government," Zask explicitly distinguishes her conception of freedom from the free-will of an isolated individual: "the insular freedom of an autonomous subject, defended by the liberal and republican tradition, is replaced by the dialogical and connected freedom (liberté dialogique et solidaire) of an independent subject" (39). "Independence" here is certainly not to be equated with an absence of resistance, interference or obstacle; on the contrary, she is referring to a "concrete and realistic" (38) kind of freedom, which develops itself in relation to and in confrontation with other subjects and objects.

This freedom-independence is perfectly exemplified, according to her, in the cultivation of land. Farming implies a relation of co-dependence and reciprocity between the farmer and the cultivated land - she talks of their "shared interests" rather than of domination and exploitation of one on the other, which would lead to the destruction of both. It becomes clear, if it wasn't already the case before, that by presenting "agriculture" as the fertile ground for democracy, Zask was never referring to the industrial intensive farming that is so widespread today.

Zask emphasizes several times the contingent character of individuation and independence. A full-blown individuality, which implies the kind of independence described above, is neither innate nor acquired once and for all. Zask insists that the development of freedom does not only require an effort on the part of the individual (such as the one found in cultivating a land), but also "favorable conditions" (43) external to the individual. The democratic government, which thrives on individual freedom, reciprocally needs to protect and foster it with legal and institutional guarantees (44). While Zask cites the importance of the Constitution and of its periodic revision, she leaves open the specific kind of governmental organization required for the development of democratic freedom.

12 The last part of the chapter, on cultivation as a means of education - with a focus on small-scale gardening - is the most explicitly Deweyan section of the book. Zask recapitulates Dewey's conception of experience as a series of anticipations, confrontations and adjustments, which is then illustrated with examples from Maria Montessori's teachings and schools. While it is not exactly clear how gardening develops individuality per se, Zask convincingly shows how it can foster independence and experimental habits of mind.

13 The second chapter centers on the social value of communal gardens, thus complementing the first chapter on individuality. The main idea defended by Zask is that communal gardens are the "privileged place" for the development of social qualities such as "solidarity, transmission, sharing, cooperation and equal task division" (69). The particular interest she finds in the study of communal gardens is their successful combination of the individual and the collective, superseding the failures of both individualism and collectivism. These "agricultural microsocieties," as she calls them (71), have first and foremost a human and social finality (before other external finalities such as profit or material security), and in that sense, exemplify a kind of sociability which "accomplishes in an informal way all the principles and rules that political democracy accomplishes at a political and legal level" (71).

14 Zask is careful to distinguish the experiments she discusses (household plots in USSR, allotment gardens, urban communal gardens, jardins ouvriers, Kleingärten, etc.) from 
seemingly similar collective farming experiments, such as USSR kolkhozes or 19th century paternalist utopias in France. The latter lack freedom of interaction, being guided by strict external rules and fixed productionist, hygienist and/or moral aims.

Accordingly, Zask is less interested in governmental agrarian reform plans than in spontaneous individual or collective initiatives and organizations, where the conditions, means and ends of farming are determined by the individuals themselves. She takes the example, among others, of communal gardens in New York City. She explains that such gardens apply a principle of equality where "equality is not postulated nor respected, but created" (109). Class, wealth and educational differences are abolished - though only, admittedly, within the specific time and space in which communal gardening occurs. Zask also defends the kind of multiculturalism naturally promoted by these experiments, which she says is less about the affirmation of an identity than about "permanent and reciprocal adjustment between different cultures" (112), in line with Malinowski's view of cultural borrowing.

More generally, Zask highlights the fact that communal gardens are at the center of urban villages, which themselves contribute to the reestablishment of social connections formerly disintegrated by the advancement of big cities. Here, one might have expected a comparative development on the effect of big cities on individuality and social relations, such as those that can be found in Dewey's remarks on the "lost individual" (Individualism, Old and New) and the "eclipse of the public" (The Public and its Problems). Such a development would perhaps have permitted to bring to light the particularity and benefits of gardening practices as compared with other, more typically urban, activities.

17 Zask ends the chapter with a section on the social and therapeutic benefits of gardening, citing examples of programs for the reinsertion of former convicts, mental health patients or veterans. Marginalized individuals learn to develop a common goal and a sense of community, and psychologically troubled patients learn how to become active caring subjects, instead of just passive objects of care. While this section's link with democracy or social virtues is less obvious at first, she convincingly explains how the restoration of autonomy through gardening (instead of paternalist methods) can be an important step towards social inclusion and reintegration.

The third chapter takes on a more explicit political focus. Zask opposes the vision, shared as much by Rousseau as by Marx and 19th century French republicans, of farmers as apolitical or, at best, reactionary. In this chapter, she defends the idea that farmers possess "their own art of governing, a taste for independence and an irreplaceable knowledge of their complex realities" (140).

Drawing on several historical studies, Zask claims that many local governments and farm managements in rural areas were "democratic" before there was even a name for it. She writes: "autonomy in villages was in fact greater at the time of monarchical and feudal institutions than it has been under the representative system of our liberal democracy" (141). While it would be difficult to present the feudal system itself as a great model of democracy, one can easily recognize with Zask that farmers and villagers were given much more power in managing their daily affairs. By referring back to these ancient systems, usually discarded altogether because of their antidemocratic character, Zask actually advocates a local democracy, against the controlling authority of a centralized state, which largely characterizes our contemporary liberal democracies. 
20 Along with local self-government, Zask praises the conceptions of property that she sees implied in democratic farming communities. The cultivation of land, according to her, goes hand in hand with a criticism of absolute and exclusive property (usually associated with liberal democracy) as well as collectivist property, and promotes instead a model of shared resources and equal distribution - here, she cites Elinor Ostrom's work on the commons (1990). In this type of organization, institutional and legal means are not used to protect individual property and enable its concentration, but rather to limit appropriation and insure the fair distribution of land plots to everyone.

21 This chapter is rich in historical and contemporary examples of farmers politically organizing themselves to fight for the management of their lands and the preservation of their rights, from 16th century German Peasants' War, to the Landless Rural Workers' Movement (MST) born in Brazil the 1980s. These movements have arisen against the expropriation of peasants and, today, the appropriation of lands by multinational corporations. Zask describes the sophisticated independent civil societies still growing in Brazil, based on shared management, shared goods and high levels of participation and involvement from individuals, where cultivating land becomes a means of empowerment for excluded farmers and other outcasts.

The fourth chapter is the shortest one; it also has less unity and richness of content than the others. It focuses on two main topics: the "everyday politics" of farming communities, and the relation between agricultural science and farmers' first-hand experience. In the first section, she expands on the concept of "common" (further analyzed by Pierre Dardot and Christian Laval in Commun. Essai sur la révolution au xxe siècle, 2014) and on the democratic practices involved in self-government, without adding much substantially new content to the previous chapters. She insists on the importance of "regular, or even daily participation of individuals to initiatives and decisions concerning their everyday affairs" (214), endorsing a demanding participatory conception of democracy that was also defended by pragmatists such as Dewey or Mary Parker Follett.

In the second section, Zask contrasts the model of agricultural science based on deliberate methods of observation, experimentation and transmission, to the agronomical movement which "stripped peasants of their status of experimenters, and reduced them to mere implementers" (219). She criticizes the idea of a rational agronomical science to be imposed on supposedly ignorant farmers hostile to progress, thus marking the end of "agriculture as experience" (221). Farmers in the agroindustry suffer from a multiple disqualification: dispossessed of their land and its products destined to be exported, working for a company, they also become mere subordinates to "expert" knowledge, their skills being reduced to a "routine know-how" (222). Zask defends a view of "agroecology" which combines modern science and the traditional and experimental knowledge of farmers, obeying to logics of preservation and sustainability instead of increasing productivity.

On the whole, Zask's book is convincing, informative and pleasant to read. It brings an important and needed focus on an underdeveloped topic in democratic theory. She succeeds in overturning caricatures attached to the rural world, and conveys an interesting view of democracy, in line with the Deweyan ideal of democracy as a "way of life." However, some critical remarks can be made concerning the formulation and demonstration of her general argument. The announced thesis of her book is that "our 
ideal of democratic freedom does not primarily come from the factory, from Enlightenment, from commerce, from cities or from cosmopolitanism, but from the farm" (7). In the next sentence, she makes it clear that she is less interested in making a historical claim about the origins of democracy, than in defending the idea that agriculture itself (broadly conceived) is naturally conducive to the development of democratic values and practices. This is a rather strong claim, even if she is careful to qualify or anticipate possible misreadings: "interactions between cultivators and their lands foster democratic ways of life and, without being their cause or exclusive origin, maintain and reinforce them" (7, emphasis added). Still, the claim implies the existence of specific traits of agriculture which make it conducive to democracy (this becomes explicit a few sentences below: "there are elements, in the very fact of cultivating land, that predispose to the development of the values associated with democracy"). However, it is not clear whether Zask succeeds in giving a full demonstration of this particular implication.

The issue pertains to the nature of the causal link which is supposed to exist between agriculture and democratic ways of life, when she claims that agriculture "fosters," "maintains" and "reinforces" them. In the examples cited by Zask in the first and second chapters, democratic modes of organization seem to both precede and condition the positive influence of agriculture on the development of farmers' independence and/or civic virtues. For example, in the first chapter, Zask acknowledges that, while also cultivating land, day laborers and slaves "do not develop any responsibility, public spirit, sense of freedom, or self-government skills" (39), as opposed to farmers in Jefferson's "ward republics." The same remark can be made about the second chapter: the "civic virtues" are developed only by a specific type of gardening, namely, that found in communal gardens (in their diverse forms). This makes it difficult to determine the extent in which agriculture per se fosters democratic ways of life, or if these examples simply illustrate the democratic mode of organization perpetuating itself in a virtuous circle, regardless of the activity concerned.

One way to answer this criticism would be to claim that agriculture naturally promotes a democratic mode of organization in the first place. Zask criticizes the collectivist organization of agriculture (taking the example of USSR's kolkhozes) in the second chapter, and intensive industrial farming in the third chapter, for being antidemocratic. In doing so, she seems to be claiming that the democratic organization of agriculture and gardening that she describes throughout her book is somehow congenial to the cultivation of land, while slave plantations, serfdom, collectivism or industrial farming would represent perverted or pathological modes of organization. For example, she claims in the third chapter that the cultivation of land goes against the idea of absolute or exclusive property, and favors instead the fair division and distribution of plots of land (145-7), and hence a certain conception of equality (158-9). While it is an interesting claim, it would deserve a longer and separate demonstration especially since it has been argued (e.g. by Grotius, or Rousseau) that property, and hence inequality, emerged with the birth of agriculture.

Perhaps the scope of the book, as well as its intended audience, could not leave room for such technical demonstrations. What she succeeds in showing in her book is amply sufficient: that the cultivation of land is particularly well-suited for democratic modes of organization; that democratically organized gardens, allotments and farms foster democratic virtues and values; that they thrive particularly well; that historically and 
to this day, farmers are inclined to organize themselves democratically, and offer viable alternatives to anti-democratic and production-driven modes of organization.

\section{AUTHORS}

\section{CÉLINE HENNE}

History and Philosophy of Science Department, Corpus Christi College, University of Cambridge cllh2[at]cam.ac.uk 